\title{
THE PAINTING OF DUJAM VUČKOVIĆ ON THE CONSTITUTION OF THE CONFRATERNITY OF HOLY CROSS IN SPLIT (1439)
}

\author{
Joško Belamarić
}

\author{
J. Belamarić \\ Institut za povijest umjetnosti \\ Centar Cvito Fisković \\ HR-21000 Split \\ josipbelam@gmail.com
}

To Igor Fiskovic - a souvenir from the space of his childhood

A painted crucifix on the first page of the Varoš confraternity of Holy Cross of 1439 can be assigned to the hand of Split painter Dujam Vuckevovic who also painted in 1442 for the Confraternity of St Anastasius a picture of their patron on the back of the first page of their regulations. With a deal of circumspection, the author put forward the hypothesis that Vučkovic did not just paint this parchment, but perhaps also wrote out the whole set of rules of the confraternity.

The polyptych (c. 1437) from St Francis' in Split-today in the Hermitage in St Petersburg - and the two confraternal constitutions from the same city definitely remove any doubt as to Vuckevićs artistic profile, although it needs to be treated as a whole at monograph level.

Key words: Dujam Marinov Vučković (Split, c. 1400 - Split 1459); the Constitution of the Confraternity of Holy Cross in Split (1439); the Dalmatian painting of the first half of the $15^{\text {th }}$ century

The Split Confraternity of Holy Cross was centred on the Church of St Mary de Moris vel de Rivo ("of the mulberries or of the brook"), later, of Holy Cross (eccl. S. Crucis vel S. Marie de Moris), whose interesting history can be summed up in a few sentences. By 1261 at the latest it had been built above a brook that flowed down to the sea to the west of the medieval city wall. ${ }^{1}$ Before the whole of the space was girt with the Baroque walls, Split was symbolically protected towards the slopes of Marjan (called Mons Golgotha or Kyrieleyson in medieval documents) by a ring of ten chapels. Apostolic visitor M. Priuli in 1603 recorded hermits alongside the church of Holy Cross, and documents record a powerful confraternity, founded in 1439, which placed in the church a Late Romanesque painted crucifix, the miracle-working features of which were preserved in a robust folk tradition. ${ }^{2}$ At the height of the Cretan War (the War of Candia), in September 1657, when the incursions of the Ottomans would reach as far as Marjan itself, the churches were knocked down, for they stood in the way of the new city fortifications. ${ }^{3}$

\footnotetext{
"This work has been fully supported by Croatian Science Foundation's funding of the project 6827 Visual Arts and Communication of Power in the Early Modern Period (1450-1800).

${ }^{1}$ P. PETRIĆ, Marjanske crkve - spomenici, in Marjane, naš Marjane, Split 2001, pp. 73-104.

${ }^{2}$ C. FISKOVIĆ, Romaničko raspelo iz crkve sv. Križa u Splitu, in Peristil 12-13 (1969-1970), pp. 5-14.

${ }^{3}$ A. DUPLANČIĆ, Splitske zidine u 17. i 18. stoljeću, Zagreb 2007, p. 25; Idem, Splitska crkva sv. Križa u 18. stoljé́u, in Croatica Christiana Periodica, Vol.11 No.19 (1987), pp. 9-16. The new Church of Holy Cross was built between 1680 and 1685. Archbishop Cosmi in his report of 1682-83 mentions this part of the city as the 'suburb of Holy Cross', and in 1687 it is first named Borgo Grande. The suburb must have existed
} 


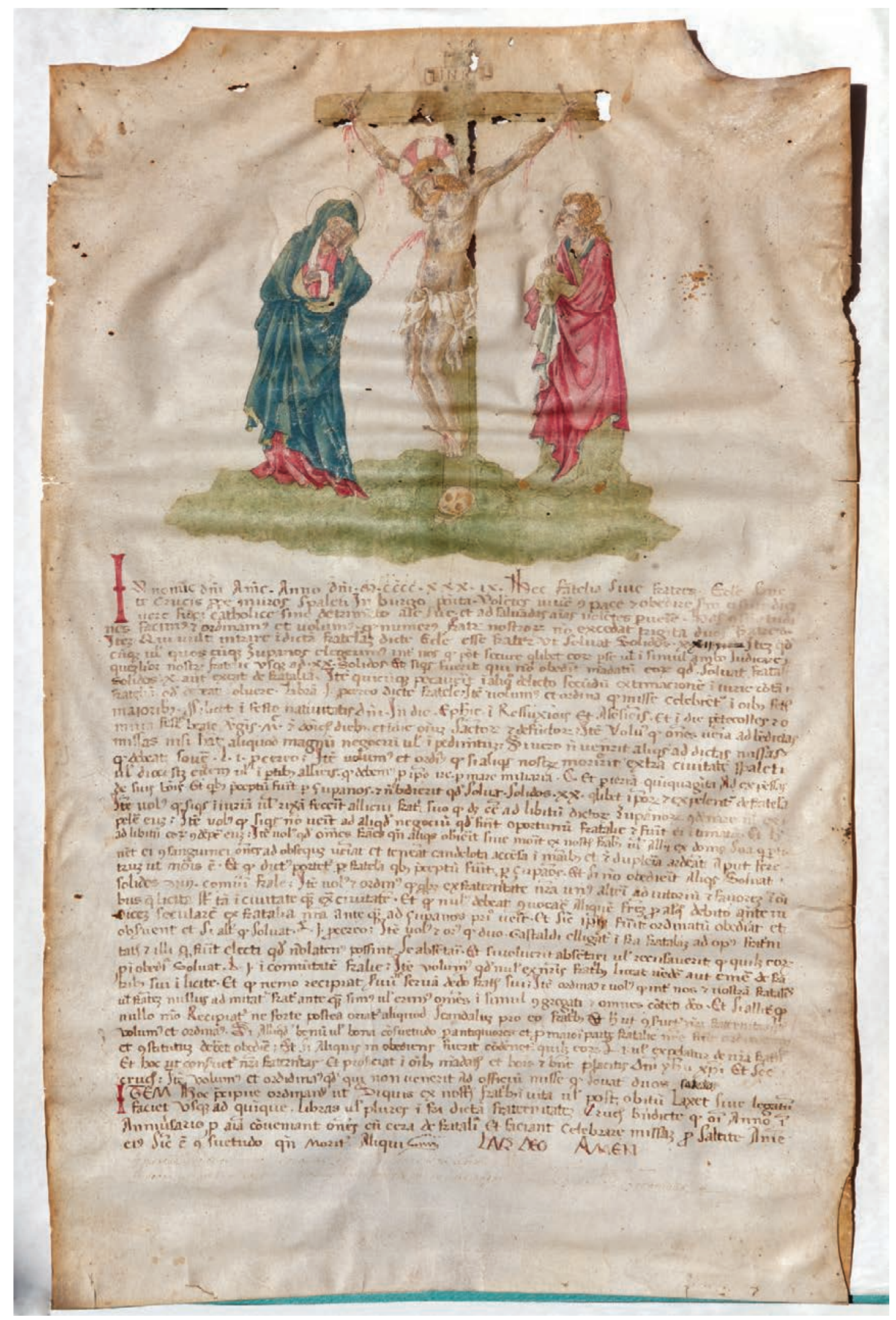


From a decision of the church council of 1186 that banned the activities of confraternities in Split, it necessarily follows that some of them were in existence as early as the $12^{\text {th }}$ century. ${ }^{4}$ Among the several fraternities mentioned in the $14^{\text {th }}$ century the best known is that of St Nicholas de Sdoria, of the sailors of Split, documented in 1349, with a book of rules dating from 1521. ${ }^{5}$ The oldest preserved rule book of any of the Split confraternities is that of the old Varoš confraternity of Holy Cross of 1439 , with an interesting painted crucifix on the first page. ${ }^{6}$ It is painted on parchment in tempera $(69.3 \times 43.5 \mathrm{~cm}$; the actual picture is $28 \times 28 \mathrm{~cm}){ }^{7}$ Without much deliberation and without any detailed graphological analyses, we can assign it to the hand of Split painter Dujam Vučković, who also painted in 1442 for the Confraternity of St Anastasius a picture of their patron on the back of the first page of their regulations. ${ }^{8}$

Dujam's style could be called post-Gothic: the Weicher Stil in the Dalmatian manner of the first half of the $15^{\text {th }}$ century. It was in fact a kind of Art Déco of the time, a style full of the poignant expressivity of weightless, asthenic figures. In the attempt to express pain naturalistically, Vučković gave his figures an almost caricatured appearance. The clothes in which they are clad follow the formula of highly decorative patterns. Cascades of folds come in sequences of calligraphic elegance, but without any real feeling for the grading of tones that might indicate the plasticity of the body. The flatness of the figures comes from the concentration on contours, which occasionally almost reduces them to silhouettes. The conclusion that Vučkovic followed the examples of the art of the young Gentile da Fabriano, mostly like filtered through the work of Michele Giambono (such as the polyptych from Fano, the Madonna and Child from the Städelsches Kunstinstitut in Frankfurt and others) is persuasive. ${ }^{9}$

This picture was probably created immediately after Vučković had taken a commission to paint the polyptych for the high altar of St Francis, for which we have the terminus ante quem of $1437 .{ }^{10}$

in 1439 , as shown by the regulations of the confraternity, at the time when it had a population of more more than 500. It was for this reason that the confraternity was founded, for mutual support, religious pieties and works of charity. A. BELAS - LJ. KARAMAN, Bratovština i crkva Sv. Križa u velom Varošu u Splitu 1439 - 1939, Split 1939.

${ }^{4}$ A. DUPLANČIĆ, Splitske bratovštine uoči ukidanja 1811. godine, in: Dalmacija za francuske uprave (1806.-1813.), Split 2011, p. 81.

${ }^{5}$ G. NOVAK, Kada je osnovana bratovština sv. Nikole u Splitu?, in Starohrvatska prosvjeta, N. S. I, Zagreb 1927: 87; G. PRAGA, Testi volgari spalatini del Trecento. Atti e memorie della Societa di storia patria, Zadar 1928; C. FISKOVIC, Umjetnički obrt XV-XVI stoljeća u Splitu, in Marulićev zbornik, Zagreb 1950, p. 146, t. XIII; G. NOVAK, Povijest Splita, sv. I, Split 1978, pp. 572- 573; A. Duplančić, Novo čitanje podataka o splitskoj bratovštini pomoraca, in Kulturna baština 33 (2006), pp. 250-251, 258.

${ }^{6}$ BELAS -KARAMAN (op. cit. n. 2); N. BEZIĆ-BOZANIĆ, Ćetiri pravilnika bratovština iz splitskog Velog Varoša, in Cakavska rič, 1-2 (1984), pp. 105-134 [reprinted in: in Veli Varoš, op. cit. n. 1].

${ }^{7}$ A. DUPLANČIĆ - R. TOMIĆ, Zbirka slika Arheološkog muzeja u Splitu, Split 2004, pp. 150-151.

${ }^{8}$ J. BELAMARIĆ, Nove potvrde za Dujma Vuškovića, in Prilozi povijesti umjetnosti u Dalmaciji 36 (1996), pp. 31-42. Pretisnuto u: idem, Studije iz srednjovjekovne i renesansne umjetnosti na Jadranu, I, Split, 2001, pp. $317-$ 329. - The reader may see that I have adopted the proposition, based on numerous archival documents, that Dujam's surname should be written Vučković and not Vušković. For this, see: E. HILJE, Dva popisa dobara splitskih slikara iz 15. stoljeća, in Radovi Zavoda povijesnih znanosti HAZU u Zadru, sv. 49 (2007), p. 302, n. 48.

${ }^{9}$ In an inventory of these more than clear influences, Andrea De Marchi concludes that Vučković must have spent time in Venice in the early 20s, a decade after the hypothesised sojourn of Blaž Jurjev. A. DE MARCHI, Un politico spalatino di Dujam Vušković a Hermitage, in Prilozi povijesti umjetnosti u Dalmaciji 36 (1996), pp. 19-29. - I do not see any "real possibility that Dujam might even have trained in the workshop of Blaž Jurjev" (according E. HILJE, Gotičko slikarstvo u Zadru, Zagreb 1999, p. 130; Dva popisa dobara splitskih slikara iz 15. stoljeća, p. 318, n. 122).

${ }^{10} \mathrm{~J}$. BELAMARIĆ, op. cit. (n. 6). 


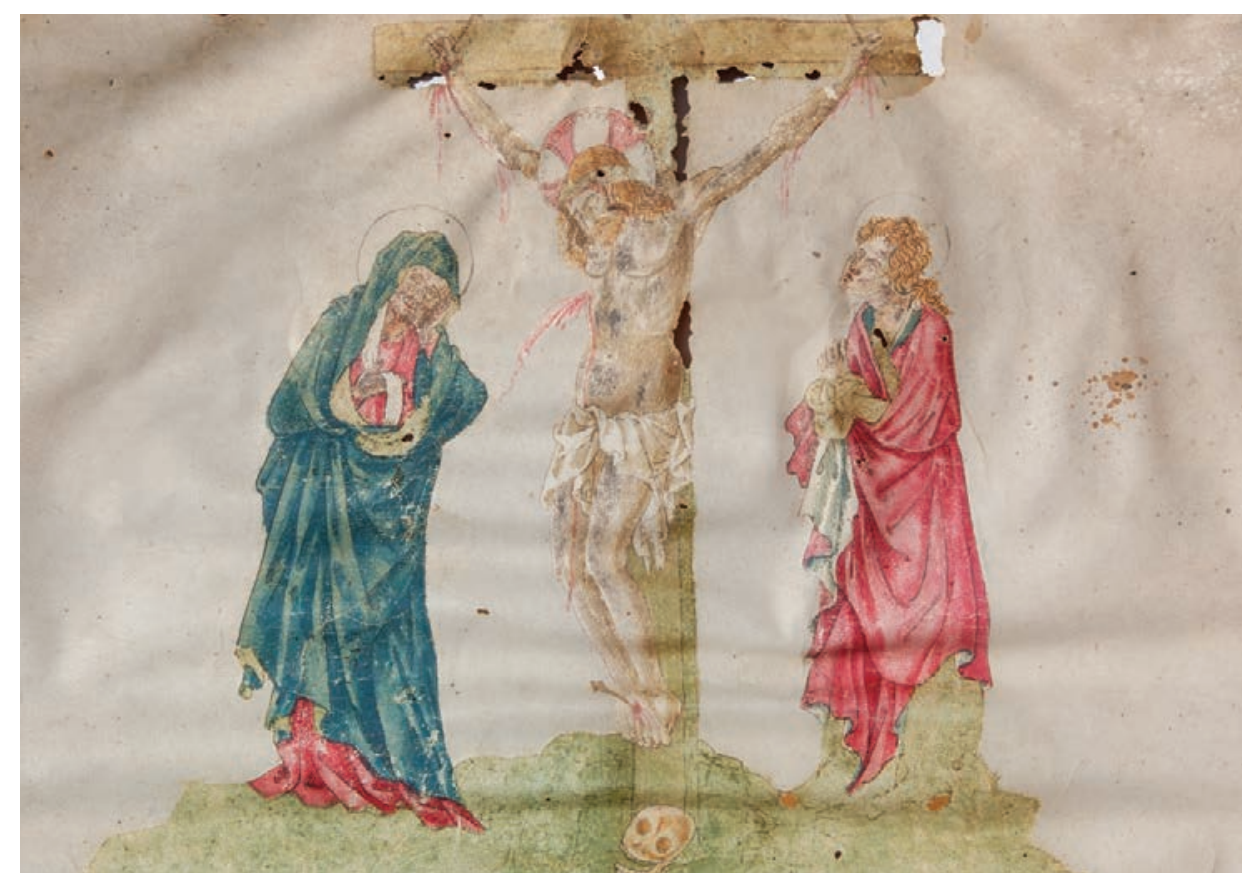

The confraternity of Holy Cross from the little suburb of the not much bigger Split was neither the Calimala nor the Arte della lana, but it did want its constitution to be decorated with the hand of the best local painter. At that time the "international style" was becoming attractive to small local craftsmen and labourers. Dujam then could not have been an innovator. The lyrical features and picturesqueness of the style - which had appeared in Venice just a couple of decades earlier - are reduced in Vučković's version to a parade of diverse effects. We can see them best on the frescoes in the Chapel of St Domnius in the cathedral, where the painter experimented with silver, gilding, lacquers, leaves of tin, pastilles of mastic - in combined fresco and secco techniques, and he must have had before his eyes effects taken from seeing niello and goldsmiths' perforation, which he applied to the details of the Ugljan polyptych. He must have astonished his milieu with all this. Unfortunately a good many of these painterly procedures in the Split frescos have become unreadable in the course of time, as a result of oxidation, or because parts or the paintings have faded or flaked off. The novelty of Vučković's style in Split can be best understand when we compare it with the still entirely Gothic reliefs of Bonino of Milan in the same chapel in Split.

The closest parallels to the figure of John on the miniature of the Rules of the Confraternity of Holy Cross can be found in the bony faces of John on the predella and the angelic musicians alongside the Throne of the Virgin in the central field of the Ugljan polyptych. The comparison is made a little difficult only by the fact that on the polyptych in Zadar few of the curls in the hairstyles of the saints have not been painted over. As in two preserved polyptychs, we can see that Dujam had problems in conceiving contrapposto. There is an interesting contrast of the flat ethereal figures and of Christ on the cross, of which Dujam, perhaps under the impression of the presence of the miracle-working crucifix in the confraternal church - endeavoured, it seems, to show the corporeality and weight. The Crucified seems more like a drawing for some wooden crucifix than a painting. ${ }^{11}$ It

\footnotetext{
${ }^{11}$ For the circulation of drawn prototypes in Vučković's workshop, see: J. BELAMARIĆ, op. cit. (n. 6). I drew attention in that place to the invaluable inventory of the house and studio of Dujam's son Marinko, in which in first place there is mention of una cassa de albedo in la qual sono desegni in carta bombaxina in peci picoli e grandi cerca mille, ali i desegni de zesso grandi, picoli, intriegi e roti numero peci cinquanta; desegni quatro in telle; Vna casseta da tegnir desegni and so on. This must have involved an impressive mass of drawings accumulated in two generations of Vučkovićes. In line with the inventory that was left by Vučković's eccentric son (he found a way out of
} 
might have been drawn like this by, for example, Dujam's contemporary, Juraj Petrović - presbyter of the Split chapter, and an excellent sculptor of an emphatic temperament. Dujam endeavoured to enhance the plasticity of Christ's limbs by hatching the flesh tones - with parallel diagonal lines, done as if he were working on a woodcut, but painted with a very fine brush. The figures of Mary and John are described in a line that is completely uninterrupted. John is clad in a bell-shaped garment the calligraphically drawn folds of which turn into a bag-shaped form around the knees. But the impression of the scene is much influenced by the degree of the damage.

The reproduction of this scene in the catalogue of the collection of paintings of the Archaeological Museum mentioned has had its colour 'rectified', and it seems that the Virgin, as it also says in the textual description, 'is clad in a red dress, blue cape and white veil', and John in "a light robe and red cloak'. ${ }^{12}$ In reality we see the typical Vučković colours, his identifiable chromatic signature. As in other works that can confidently be ascribed to him, the general impression of this scene is based on a mordant assonance of contrasting colours. ${ }^{13}$ John's cloak is cyclamen coloured, and the Virgin's in-

bankruptcy in a Venetian galley of war, on which he was captured in 1473 by the Turks off the island of Scalimena - mythical Lemnos in the Aegean) we can almost in fine detail reconstruct his studio, more like a junk shop in which every third or fourth item is mentioned as being uechio, rotto, strazato, inbratada. However, also mentioned are various paintings, complete or just begun, easels, a stone relief polyptych, a block of coloured marble (Vna piera de marmoro da colorie tre altre), a block of porphyry (Porfido vno grando da colori), a chest full of wood carvings (intaii de legno), five swords with no scabbards(spade cinque triste senza uazine). Although I once thought of publishing this inventory complete, it was done excellently by Emile Hilje, publishing it, for he also added to some suggestive detailed commentaries a handful of previously unknown documents about the personality of Marinko Vučković. They are only at first glance irrelevant to art historians (since not one of them mentions his own painting), for they vividly sketch out the time and setting in which magister Marinello Uuçchouich pictor de Spaleto worked, touching on names like George the Dalmatian, Juraj Ćulinović (Giorgio Schiavone) and Francesco Squarcione. See, then: E. HILJE, Dva popisa (op. cit. in n. 6), pp. 289-337.- Naturally such drawings, although probably not in such great numbers, must have existed in every painter's workshop. Antun Restinović, for example, in a will of November 22, 1447, left to Dujam Vučković (his assistant from 1445) a box with drawings for works of painting. ${ }^{12} \mathrm{R}$. Tomić in the catalogue: A. DUPLANČIĆ - R. TOMIĆ, op. cit. (n. 5), pp. 150-151. Here it is said that the crucifixion "does not show any very marked similarities with some concrete painters that are mentioned at the time in the city [Split] and whose works are preserved."

${ }^{13}$ The fragmentarily preserved frescos on the vaults of the Chapel of St Domnius in the Split cathedral, discovered in 1958, are his most important work. They might even be the first of his works, or the earliest that has been preserved. Davor Domančić on the basis of this fresco established a framework for the painter's oeuvre in the centre of which is the Polyptych from Ugljan (today in the collection of the Monastery of St Francis in Zadar), and parts of the polyptych from the high altar of the Church of St Francis on the shore in Split (today in the Hermitage in St Petersburg). See: D. DOMANČIĆ, Freske Dujma Vuškovića u Splitu, in Prilozi povijesti umjetnosti u Dalmaciji 11 (1959), pp. 41-58; A. DE MARCHI, Un politico spalatino di Dujam Vušković a Hermitage, op. cit. (n. 7), pp. 19-29.

In the contract for the Split fresco of January 3, 1429, Dujam is not mentioned except in concert with the painter Giovanni da Pietro with whom he worked for the next twenty years. (C. FISKOVIC, Nekoliko dokumenata o našim starim majstorima, in Vjesnik za historiju i arheologiju dalmatinsku, sv. LII. (1950), pp. 191-192, 208.) Hence E. Hilje, attempting to define the relation of the two, came to the idea that in this company the Milanese painter had the leading role. (E. HILJE, Gotičko slikarstvo u Zadru, Zagreb 1999, pp. 122-133; E. HILJE - R. TOMIĆ, Slikarstvo. Umjetnička baština zadarske nadbiskupije, Zadar 2006, pp. 168-180.) Giovanni da Pietro among the many Zadar documents appears individually in some painting job only in a smallish altarpiece in Znojaci, for the trifling value of 14 and a half ducats), and here he was bound to follow the measures and form of the altarpiece that was on the altar of St Catherine's in Pag. Outside Zadar, he is hardly mentioned at all, and in Split we do not hear of him after his contract for the Chapel of St Domnius. On May 21, 1447, the Zadar polyptych was standing on the altar of the freshly consecrated Franciscan Church of St Jerome on Ugljan. (I. PETRICIOLI, O važnijim umjetninama u franjevačkom samostanu u Zadru, in Zbornik samostana sv. Frane u Zadru, Zadar 1980, pp. 117-118.) Dujam and Giovanni da Pietro had broken off their partnership (which was perhaps more commercial than artistic) before April 9, 1446. In fact, at the beginning of 1445, Vučković had already entered into a business partnership with another painter in Split, 
digo against a green ground. The painter first of all put down on the parchment a basic warm-green ground, except in places where the flesh tones of the three figures would be. He made masterly use of the tone of the faded parchment, reducing it with the density of top, darker layers of blue and vermilion that accordingly reflects it as cyclamen. On the perisome he uses it to shape the light folds, without any toning, only with a strengthening of his drawing and hatching. But unfortunately only the painted film that was put on delicately and thinly is still in existence. The lower part of John's cape and the wood of the cross, which were more three-dimensional in their colour, that is, painted with a thick layer of tempera, clearly over the course of time turned into craquelure. The cracked paint gradually flaked off, and the original chromatic relationships will be able to be reconstructed only by a reading of the dots of paint that are still to be seen only microscopically. Hence we see the painting today in a kind of plastic inversion. ${ }^{14}$ Only with more attentive reading can we realise, for example, the importance that Vučković assigned to the depiction of the hill of Golgotha with the skull of Adam, onto which dripped the blood from the wound on Christ's legs, visible now only in minute traces. ${ }^{15}$

We might mention in passing that the occasional "granello di vero" (according to Longhi's phrase for Gentile's painting) will be found. This grain of reality might in this Crucifixion be seen in the line of blood that drips down Christ's body, running under the perisome; or in the depiction of the finch in the Ugljan polyptych; or on the lawn on which the brothers of the St Anastasius Confraternity kneel with the flora that comes from some local tacuinus sanitatis.

To end I would put forward, with a deal of circumspection, the hypothesis that Dujam Vučković did not just paint this parchment, but perhaps also wrote out the whole set of rules of the confraternity. ${ }^{16}$ Notwithstanding the different purpose of the writing, a comparison of the calligraphic letters with which the verses of a hymn in honour of the Virgin are written on her wimple with the apparently routine chancellery Gothic that is used for the writing of the constitution of the Confraternity of Holy Cross, some specific details could well be pressed into service to indicate the same hand. But a review of this proposal should be left to those more initiated. ${ }^{17}$

Antun Restinović. (E. HILJE, Dva popisa, op. cit. in n. 6, p. 292, n. 15.) This then excludes the naturalised Lombardian painter (who died early in 1448), not only from being a hypothetical author of but also a collaborator on the Ugljan painting. The polyptych from St Francis' in Split (the church in which Dujam ordered himself to be buried, and he died probably in 1458 or in the first half of 1459) and the two confraternal constitutions from the same city definitely remove any doubt as to Vučković's artistic profile, although it needs to be treated as a whole at monograph level. ${ }^{14}$ I am grateful to restorer Žana Matulić Bilač for help in the technological aspects of this painting.

${ }^{15}$ The representation of the blood falling on Adam's skull below the cross corresponds to medieval apocryphal tradition that mirrors the opinion of the symbolic equivalence of blood and water in the rite of baptism, according to which Adam was baptised in the blood of Christ. More: M. SEIDEL, Arte italiana del Medioevo e del Rinascimento, vol. 1: Pittura. (article: Giotto. La croce di Santa Maria Novella), Venezia, 2003, pp. 110-112.

The painting needs a restoration operation, for the parchment has obviously started to gather in the last ten years, precisely in the upper part. In such an operation, the graphic pencil interventions with which someone attempted to restore parts of the painting should be probably removed.

${ }^{16}$ Entirely incidentally, in 1450 one of the Split confraternities (perhaps that of Holy Cross) protested against Dujam's making free of their resources. J. BELAMARIĆ, op. cit. (n. 6): 10.

${ }^{17}$ There are some suggestive data in the inventory of the studio left by Marinko Vučković that as well as books (in vulgar) there are: i: Quaderneti 32 longi e liberi de raxon 6 grandi, and ii: Quaderni 13 de diuersi experimenti [sic !]. Marinko's studio must have been in equal measure Dujam's as well, and his inventory should be seen as a deposit of the decades-long operations of the workshop that was, of course, closely collaborating with a number of others. The quantity of drawings and artworks mentioned in the inventory are entirely out of proportion with the recorded artistic work of Dujam's son. But speaking of the possibility that the text of the Regulations might have been written by Dujam, it is perhaps telling that Marinko himself, in his flight from the reality of Split in which he had lost control of his everyday business, found a way out taking ship in a Venetian war gallery. He took employment as a writer. Here there is no need to list other examples from which it can be seen that the Dalmatian painters also knew how to write, nicely too, like Restinović and Blaž Jurjev who, for example, on the well-known Ciovo polyptych wrote his signature in Latin with great fluidity, while with similar surety under the decorated frame of the polyptych in Trogir Cathedral he wrote out his expenses for meat in Glagolitic script. 
Dujam did not achieve the linear melodiousness or the almost metaphysical aspect of Blaž's figures. He did achieve either the warm humanity that Nikola Vladanov showed in his polyptych painting Our Lady of Mercy as if she were some Sibenik matron of the time or the confraternity members whose features could have been derived only from attentive observation of faces. Still, he did leave recognisable works of original chromatics, a very specific version of post-Gothic Soft Style. The painting made for the Holy Cross Confraternity in a suburb of Split is one more tessera in the mosaic that still needs to be reconstructed for us to understand the full reach of Vučković's oeuvre.

transl. Graham McMaster

\section{SLIKA DUJMA VUČKOVIĆA NA MATRIKULI BRATOVŠTINE SVETOG KRIŽA U SPLITU (1439)}

Najstariji sačuvani pravilnik neke od splitskih bratovština je onaj varoške bratovštine sv. Križa, iz 1439. godine, sa oslikanim prikazom Raspeća na prvom listu. Naslikan je temperom na pergameni (69,3 x 43,5 cm; sâm prikaz: 28 x 28 cm). Bez mnogo premišljanja može se pripisati ruci splitskog slikara Dujma Vučkovića, koji je 1442. i bratovštini sv. Staša naslikao njihovog zaštitnika na poleđini prvog lista njihova Pravilnika.

Dujmov stil mogli bismo nazvati post-gotičkim: Weicher Stil na dalmatinski način prve polovine 15. stoljeća. Bio je zapravo nekom vrstom onodobnog art-decoa, stil pun slatkogorke ekspresivnosti bestežinskih asteničnih likova. U pokušaju da naturalistički iskaže bol, Vučković je licima dao gotovo karikaturalan izgled. Odjeća kojom su zaogrnuti slijedi formule izrazito dekorativnih obrazaca. Slapovi nabora nižu se kaligrafskom elegancijom, ali bez pravog osjećaja za gradiranje tonova kojima bi se naznačio plasticitet tijela. Plošnost likova dolazi iz koncentracije na konture, koje ih ponegdje svode gotovo na siluete. Uvjerljiv je zaključak da je Vučković slijedio primjere umjetnosti mladog Gentile da Fabriana, najvjerojatnije kroz filtere djela Michele Giambona (poput poliptiha iz Fana, Madone s Djetetom iz Städelsches Kunstinstitut u Frankfurtu i drugih).

Ovaj prikaz je nastao po svoj prilici neposredno nakon što je Vučković primio narudžbu slikanja poliptiha za glavni oltar sv. Frane, kojemu imamo terminus ante quem (1437). Družba brašćine Sv. Kri$\check{z} a$ iz malog predgrađa ne mnogo većeg Splita nije bila ni Calimala niti Arte della lana, ali je željela da joj matrikulu svojom rukom ukrasi najbolji domaći slikar. Sofisticirani "Internacionalni stil" postao je u to vrijeme privlačan i malim lokalnim obrtnicima i težacima.

Dujam dakako nije mogao biti inovator. Lirske odlike i slikovitost tog stila - koji se i u Veneciji pojavio samo par desetljeća ranije - u Vučkovićevoj su izvedbi svedeni na paradu raznovrsnih efekata. Najbolje ih opažamo na freskama u kapeli sv. Dujma u katedrali, gdje je slikar eksperimentirao sa srebrom, pozlatom, lakovima, listićima kositra, pastiljama od mastiksa - u kombiniranoj fresco i secco tehnici, a treba imati pred očima i efekte preuzete promatranjem niella i zlatarskog punciranja, koje je primijenio na detaljima Ugljanskog poliptiha. Zacijelo je time zadivio svoju sredinu.

Najbliže paralele Ivanovu licu na minijaturi Pravilnika bratovštine sv. Križa naći ćemo u košćatim licima Ivana na predeli i anđela svirača uz Gospino prijestolje u središnjem polju Ugljanskog poliptiha. Komparacije otežava jedino činjenica što je na poliptihu u Zadru malo koja kovrča u frizurama svetaca ostala nepreslikana. Kao i na dvama sačuvanim poliptisima, uočavamo da je Dujam imao problema s koncipiranjem kontraposta. Zanimljiv je kontrast plošnih eteričnih likova i Krista raspetog na križu, kojemu je Dujam - možda i pod sugestijom prisustnosti čudotvornog Raspeća u bratovštinskoj crkvi - nastojao, čini se, prikazati tjelesnost i težinu. Plasticitet Kristovih udova Dujam je pokušao pojačati šrafiranjem inkarnata - paralelnim dijagonalnim crticama, izvedenim kao da radi na drvorezu, no slikanim najfinijim kistom.

Kao i na ostalim djelima koja se sa sigurnošću mogu pripisati Vučkoviću, opći dojam ovog prizora kalkuliran je na jetkim asonantnim kontrastima boja. Ivanov plašt ima boju ciklame, Gospin indiga 
na zelenoj podlozi. Slikar je najprije na pergamenu postavio osnovnu toplozelenkastu podlogu, osim na mjestima inkarnata triju likova. Majstorski je koristio ton izbijeljene pergamene reducirajući ga gustoćom nanosa gornjih, tamnijih slojeva plave i cinobera koji zbog toga reflektira kao boja ciklame. Na perizomi ga koristi da oblikuje svijetle nabore, bez ikakva toniranja, samo dodatnim pojačavanjem crteža i šrafiranjem. Očuvao se nažalost jedino bojani sloj koji je bio delikatno, tanko nanesen. Donji dio Ivanova plašta i drvo križa, koji su bili bojom plastičniji, odnosno slikani debljim slojem tempere, s vremenom su očito pretvoreni u mrežicu krakelira. Ispucala boja postupno je otpala, pa će izvorne kromatske odnose biti moguće rekonstruirati tek čitanjem točkica boje koje se uočavaju još samo pod mikroskopom. Stoga sliku danas vidimo u svojevrsnoj plastičnoj inverziji.

Na kraju se iznosi, dakako uz mnogo opreza, hipoteza da Dujam Vučković ovu pergamenu nije samo oslikao, nego na njoj možda ispisao i čitav Pravilnik bratovštine. Bez obzira na drugačiju namjenu pisanja, usporedba kaligrafskih slova kojim su na Ugljanskom poliptihu pisani stihovi himni u čast Bogorodice na Gospinom maforiju, s naizgled rutinskom kancelarijskom goticom kojim je napisana matrikula brašćine sv. Križa, možda bi mogla po više specifičnih detalja ukazivati na istu ruku.

Dujam nije dosegao linearnu melodioznost ni gotovo metafizički aspekt Blaževih lica. Nije dosegao ni toplinu ljudskosti koju je na svom poliptihu prikazao Nikola Vladanov slikajući Gospu Misericordiju poput neke šibenske onodobne matrone i bratime čije su fizionomije mogle nastati samo pomnim promatranjem lica. Pa ipak, ostavio je prepoznatljiva djela originalne kromatike, posve specifičnu varijantu post-gotičkog Lijepog stila. Slika nastala za bratovštinu Svetog Križa u splitskom predgrađu, još je jedna tesera u mozaiku koji tek treba rekonstruirati, da bismo razumjeli pun doseg Vučkovićeva opusa.

Poliptih iz splitskog sv. Frane (dakle, iz crkve u kojoj se Dujam dao pokopati, a umro je vjerojatno 1458. ili u prvoj polovici 1459.) - danas u Ermitažu - te dvije splitske bratovštinske matrikule, definitivno otklanjaju svaku sumnju u Vučkovićev umjetnički profil, premda će ga u cjelini tek trebati monografski obraditi.

Ključne riječi: Dujam Marinov Vučković (Split, oko 1400 - Split 1459); matrikula bratovštine Svetog Križa u Splitu (1439); dalmatinsko kasnogotičko slikarstvo 